UDK: 005.334:368

POSLOVNA EKONOMIJA

BUSINESS ECONOMICS

Godina X

Originalni naučni rad

Broj II

Str $43-65$

doi 10.5937/poseko10-12637

PhD Dejan S. Drljača ${ }^{1}$, Coordinator for Insurance Risks Management

Dunav Insurance Company a.d.o., Belgrade

\title{
RISK ASSESSMENT THROUGH MATRIX MODEL IN INSURANCE COMPANIES
}

\begin{abstract}
Establishment of the Risk Management System and Own Risk and Solvency Assessment in insurance companies, apart from implementation of a set of models, which ensure measurement of potential losses and assessment of the risk size, implies prior definition of risk priorities and limits for risk assumption, as well as periodical review of framework for risk recognition, measurement and assessment. Thus, optimal allocation and use of available financial, technical, information, human and all other available resources is ensured.

When determining the procedures and establishing appropriate risk management organization, the insurers firstly select, at the first hierarchy level, models for quantification of possible losses, test the adequacy of calculated technical reserves by using the Liability Adequacy Test and assess levels of individual risks. At the second hierarchy level, they select models for measurement and assessment of solvency, i.e. assessment of capital adequacy and choice of models for assessment of overall exposure at the level of a company as a whole, among which the central place is taken by the matrix model. A matrix model ensures a documented and systematic approach to risks by providing information comparable in time and partially among the insurance companies themselves.
\end{abstract}

Keyword: adequacy, risks, assessment, solvency, matrix, risk management, models, measuring, company...

${ }^{1}$ dejan.drljaca@dunav.com 


\section{INTRODUCTION}

The subject matter of this paper is the development and presentation of a model based on a 10x8 risk matrix which, on the one hand (starting from the risk probability and severity/consequences) provides for the assessment of the size of individual risks and, on the other hand, in an original way (starting from the established quantitative ratios among the risks and using the appropriate weighting system) provides for the assessment of group risks (including the risk subgroups) and of the amount of overall exposure of the insurer, particularly with regard to non-life and life insurance.

The aim of this paper is to present, in theory and practice, both the risk assessment methodology, possibilities and ways of establishing a connection among a large number of risks and the methodology for summarizing various and often unrelated information through a common denominator, in the form and content suitable for the presentation and disclosure of information relevant to their users (the company management, supervisors, owners, insured persons and interested public).

Along with the presentation of theoretical basis of the risk assessment matrix model and the processes of measurement and assessment of the size of a large number of individual risks which differ by nature, character and effect (classified in risk groups), it shall be seen how the overall exposure at the Company's level can be identified and assessed by adequate methodological process of assessing the size of group risks.

The paper is structured so as to consider: application possibilities, characteristics and specific features of the model; theoretical base of the matrix model as presented through the risk matrix (10x8), created as a result of years of experience and work in the insurance industry; and the risk assessment processes.

Although, at the first glance, it can be concluded that the matrix model is a widely applied methodological apparatus in insurance companies, the practice has shown that, so far, it has actually been much more applied in the military industry and occupational health and safety than in insurance companies (noting, however, that this issue remains insufficiently dealt with in the papers of scientific staff and the insurance professionals). As opposed to the US military standards and risk matrices applied in other areas of economic and social system (where $4 \times 4,4 \times 5$ and $4 \times 6$ matrices are mainly used to define the ranks of probability and consequences of occurrence of the risk of occupational diseases, injuries, various types of losses, etc.), this paper presents 10x8 matrix which take into account the insurance theory and practice, as much as possible. 


\section{APPLICATION OF MATRIX MODEL AND ITS CHARACTERISTICS}

In order to essentially fulfill the quantitative and qualitative requirements of risk management, the administrative bodies of the insurance company must have the information on the amount of possible losses, estimated size of individual and group risks, estimated amount of overall exposure of non-life and life insurance and always have at their disposal a set of possible measures and activities which would ensure that certain risks are reduced to a size not exceeding the Insurer's risk carrying capacity. By applying this approach, a direct link is established between solvency and/or compliance with capital requirements and requirements for adequacy of recognized liabilities of the Insurer on the one hand and key requirement of protecting the interests of insured persons, on the other hand. At the basis of the assumption surfacing or specification process is a set of techniques for helping decision-makers to uncover and to analyze the critical key assumptions upon which their policies rest (Mitroff et al., 1979, p. 586).

The insurance companies assess the amount of their overall exposure at the level of the company as a whole, i.e. the size of the identified risks per risk groups, whereby the risk size of a particular risk group is defined by a larger number of individual risks. The amount of overall exposure of non-life and life insurance is determined by the risk size of particular risk groups, noting that each risk group is defined by a larger number of individual risks. Theoretically, there are different approaches and ways of risk allocation. The National Bank of Serbia has classified all risks under the following seven risk groups2: (1) Insurance risks (including a larger number of risk sub-groups); (2) Liquidity risks; (3) Counterparty default risks; (4) Market risks; (5) Operating risks; (6) Legal risks; and (7) Other significant risks (reputational and other).

Matrix model is characterized by a special combination of quantitative and qualitative risk approach, meaning that the consequences of individual risks are sometimes measured and evaluated by applying the quantitative methods and sometimes (with particular risks) by applying the qualitative methods based on personal experience, expertise, knowledge and skills of the assessor to turn a large number of diverse qualitative information (on the cause and effect in the form of losses and adverse occurrences) into the information suitable for the qualitative ranking of the risk severity/consequences and for the assessment of probability. In narrower sense, matrix model belongs to the group of qualitative models; however, in a broader sense, i.e. in the context of a preliminary

\footnotetext{
${ }^{2}$ Decision on the System of Governance in an Insurance/Reinsurance Undertaking, IO NBS No. 48 of $51 / 2015$.
} 
application of quantitative methods, we can say that it is a combination of a quantitative and qualitative model.

Solvency II project introduces a comprehensive approach to the risk management process, which is why, in addition to the quantitative requirements, it has dedicated two pillars to qualitative requirements, the reporting system, the system of internal control and insurance supervision. While focusing on testing of adequacy of recognized technical reserves (calculated by the best estimate method), capital adequacy testing, stress testing, testing the ability of insurers to comply with the qualitative requirements in the risk management process and with the investment rules, we create the information base that is crucial for the implementation of the quality reporting system for management, shareholders and supervisory authority. Already now, we can say that the scope, complexity and demands of Solvency II project will inevitably provoke resistance and occurrences which will cause major complications and slow down the establishment of the systemic risk management process. Conflicts are part of the resistance to changes and their effect and occur even when the effect of changes is carefully planned and realized (Čabrilo et al., 2013, p. 100). Therefore, it is essential to introduce new information technologies and work on education of the insurance industry administration, management and employees in order to be able to apply new risk management techniques and methods. An effective and comprehensive risk management system is based on a precise definition of objectives and, above all, on the organized care of the risks. Such an approach strongly guarantees preserving the solvency of insurers, creates preconditions for successful implementation of the strategies approved by the company's management, ensures minimization of exposure and, ultimately, supports the realization of the insurer's business objectives and plans.

Develop a planned approach for safety task accomplishment, provide qualified people to accomplish the tasks, establish the authority for implementing the safety tasks through all levels of management, and allocate appropriate resources, both manning and funding assure the safety tasks are completed. (USA Department of defence, 1993, p. 101-1).

By conducting the early warning tests and elaborating on scenarios, continuous control is exercised over the adequacy of recognized liabilities and capital of the insurer, which ultimately leads to strengthening of his financial position. For the reliable and efficient risk assessment, it is essential that the information meet particular criteria and preconditions, above all: (1) the availability and timeliness (available and prepared within the required time limits); (2) the relevance and comprehensiveness (that they contain all relevant pieces), (3) the reliability and accuracy (that one can rely on them), (4) the preciseness (focus on the subject-matter) and (5) compliance (comparable, time consistent, interrelated, of adequate structure). 


\section{BASES OF MATRIX MODEL}

Matrix model is based on determining or assessing the risk severity (consequences) and probability of occurrence of particular risks and establishing a logical connection between risk consequences and probability of occurrence. Generally, the size of risk represents the product of risk severity and probability; however, to assess the exposure of particular risk groups, one must also consider the correlation, i.e. the connection and relations between individual risks.

It is worth noting that sometimes it is very difficult to precisely determine the boundary between the individual risks, which points to the need to always and without exception observe the risks in correlation with one another, especially when it comes to credit and market risks (Drljača, 2011, p. 98). Solvency requirements of the previous regime are not securing the fulfilment of the goals contained in the directives of the European Union, as well as strengthening market discipline and competition between insurers, and the risks of structural imbalance of assets, risks regarding investment of insurance assets, risks of variable interest rates, foreign exchange rates, risks of changes in the capital market and evaluation of market risks, were not adequately covered. Therefore, the current regime of Solvency II was activated that is much better in recognising relationships between insurer's capital, its market position and requirements for protection of insured's interests. Key objective of Solvency II requirements regarding capital requirements, property management quality, capital and liabilities is basically full protection of interests of insured persons. These rules requiring of insurers to identify, measure and estimate broader group of risks; to introduce new models for calculation of capital requirements and future liabilities (best estimate method), early warning tests, scenarios and risk transfer techniques and extremely strict requirements regarding disclosure. Adequacy of calculated technical reserves does not provide a satisfactory level of safety in case of more significant impairments of assets and funds of insurers, as well as in case of significant deviations between amounts of settled claims and actuarially expected amounts of liabilities based on claims. Therefore, losses due to impairment of asset, difficult collection of low liquid securities that are difficult to market and inability to collect receivables from reinsurers must be covered by a solvent capital. It can be said that the objective of the solvency II is to show that the capital adequacy is the key factor for insurers' safety and a guarantee of capability of an insurer to settle any future liabilities.

Solvency II, the actual situation in the capital market, the increasing globalization, the changing situation regarding tax preference and the increasing competition will challenge the industry (Baller, 2012, p. 195). Solvency II project defines categories of Minimum Capital Requirement (MCR) and Solvency Capital Requirement (SCR), where decline of insurer's capital below Minimum Capital Requirement means that the company is facing an 
unacceptably high risk and possible loss of work permit. Insurer's capital at the level of Solvency Capital Requirement is reduced to the risk of default in an acceptable level, where SCR corresponds to the value of net assets under risk, at the level of trust of $99.5 \%$ in one year. Insurer's assets are valued according to the fair value, i.e. assets should be equal to the amount for which it can be exchanged between known market participants. Level of liabilities recognised in financial statements should correspond to present value of future liabilities. More precisely, liabilities are valued at the level that corresponds to the amount which the insurer should provide in case of transfer of its liabilities to another insurer, which is performed by using the best estimate method, taking into account the expected level of costs, retail prices growth, contracted insured's rights in insurance contract (return of premium, bonuses, profit share and the like) and by using a no-risk interest rate (Drljača, 2011, p. 312).

Figure 1 - Overview of the Economic Balance Sheet

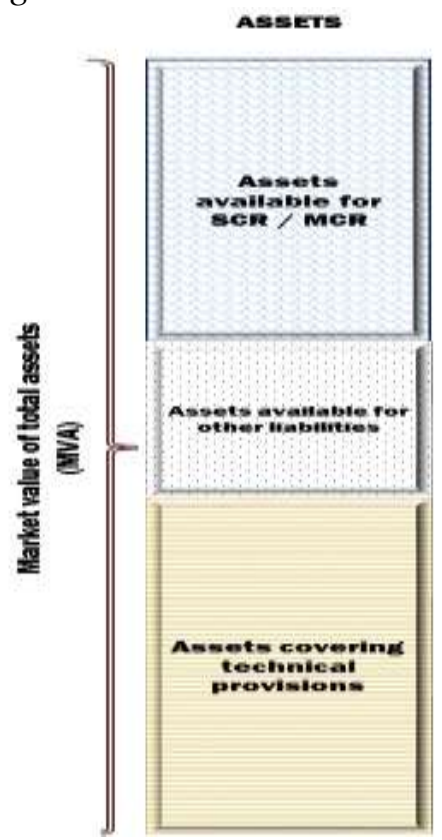

LIABILITIES

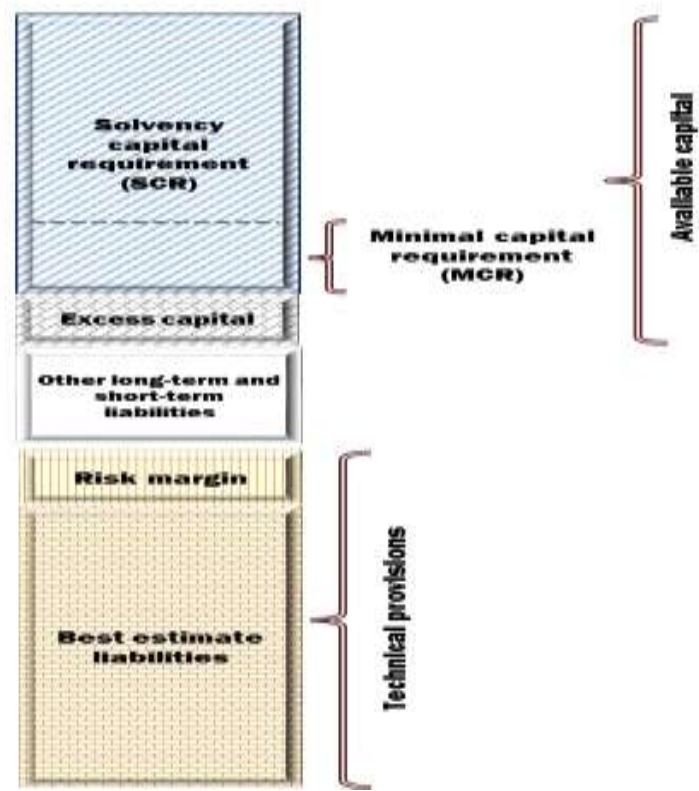

Source - Author, based on: Directive 2009/138/EC of the European

Parliament and of the Council of 25 November 2009 on the taking-up and pursuit of the business of Insurance and Reinsurance (Solvency II)

In order to ensure that the assessed risk size falls within the predefined range, the product of risk probability and severity is multiplied by the coefficient of risk rank determination. Figure 2. below shows a standard 10x8 risk matrix, where the consequences are expressed in 8 ranks (levels) and probability in 10 ranks, using the 1.25 coefficient (which provides that, when ranking the risk 
consequences within the range from 1 to 8 , the estimated risk size falls within the range from 0.1 to 10$)$.

Figure 2 - 10x8 risk matrix
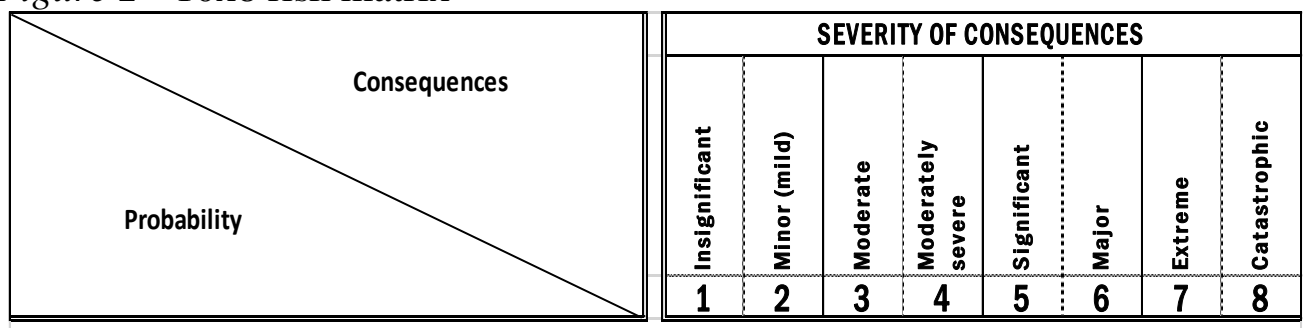

\begin{tabular}{|c|c|c|}
\hline \multicolumn{3}{|c|}{ The coefficient of determination of ranking risk(from 0,1 to 10) } \\
\hline \multirow{10}{*}{ 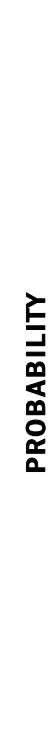 } & Practically unlikely event & 0,1 \\
\hline & Hardly identifiable probability & 0,2 \\
\hline & Highly unlikely, unusual event & 0,3 \\
\hline & Highly unlikely event & 0,4 \\
\hline & Relatively likely event & 0,5 \\
\hline & Moderately likely event & 0,6 \\
\hline & Likely event & 0,7 \\
\hline & Highly likely event & 0,8 \\
\hline & Expected event & 0,9 \\
\hline & Certain event & 1 \\
\hline
\end{tabular}

\begin{tabular}{|c|c|c|c|c|c|c|c|}
\hline \multicolumn{8}{|c|}{1,25} \\
\hline 0,1 & 0,3 & 0,4 & 0,5 & 0,6 & 0,8 & 0,9 & 1,0 \\
\hline 0,3 & 0,5 & 0,8 & 1,0 & 1,3 & 1,5 & 1,8 & 2,0 \\
\hline 0,4 & 0,8 & 1,1 & 1,5 & 1,9 & 2,3 & 2,6 & 3,0 \\
\hline 0,5 & 1,0 & 1,5 & 2,0 & $\underline{\underline{2,5}}$ & 3,0 & $\underline{\underline{3,5}}$ & 4,0 \\
\hline 0,6 & 1,3 & 1,9 & $\underline{2,5}$ & $\underline{\underline{3,1}}$ & 3,8 & 4,4 & 5,0 \\
\hline 0,8 & 1,5 & $\underline{2,3}$ & 3,0 & $\underline{3,8}$ & 4,5 & 5,3 & 6,0 \\
\hline 0,9 & 1,8 & 2,6 & $\underline{3,5}$ & 4,4 & 5,3 & 6,1 & $\underline{7,0}$ \\
\hline 1,0 & 2,0 & $\underline{\underline{3,0}}$ & 4,0 & 5,0 & 6,0 & $\underline{\underline{7,0}}$ & 8,0 \\
\hline 1,1 & $\underline{\underline{2,3}}$ & $\underline{\underline{3,4}}$ & 4,5 & 5,6 & 6,8 & $\underline{\underline{7,9}}$ & $\underline{\underline{9,0}}$ \\
\hline 1,3 & 2,5 & $\underline{3,8}$ & 5,0 & 6,3 & $\underline{\underline{7,5}}$ & $\underline{8,8}$ & $\underline{10,0}$ \\
\hline
\end{tabular}

Source - Author, 2016.

This paper starts from the most generally accepted classification of risks into five risk categories, namely: (a) Insignificant risk (b) Low risk; (c) Medium risk; (d) High risk and (e) Extreme risk, with the need to define appropriate quantitative ranking for each risk category. Defining the risk size is an extremely sensitive procedure because, in addition to the assessment of probability of occurrence of particular risks, it includes determining the risk consequences. The risk consequences are mainly determined starting from the possible impact of risks on:

- Adequacy of calculated technical reserves;

- Coverage of technical reserves;

- Compliance with capital requirements; 
- Financial standing of the Insurer;

- Functioning of business processes;

Figure 3 below shows the classification of risks, qualitative risk descriptions, quantitative risk rankings as well as the measures and activities undertaken at each level of assessing the risk size.

\begin{tabular}{|c|c|c|c|c|c|c|}
\hline RISK LEVEL & Qualitative description of risk level & \multicolumn{4}{|c|}{ Quantitative ranking } & Measures \\
\hline $\begin{array}{l}\text { INSIGNIFICAN } \\
\text { T RISK }\end{array}$ & $\begin{array}{l}\text { Risk realisation produces insignificant } \\
\text { consequences on: a) insurer's solvency, } \\
\text { adequacy of technical provisions and their } \\
\text { coverage or b) efficient functioning of business } \\
\text { processes. }\end{array}$ & od & 0,10 & do & 0,59 & $\begin{array}{l}\text { * No measures or activities for risk minimisation are } \\
\text { required. }\end{array}$ \\
\hline MINOR RISK & $\begin{array}{l}\text { Risk realisation produces minor consequences } \\
\text { on: a) solvency, adequacy of technical provisions } \\
\text { and their coverage or b) efficient functioning of } \\
\text { insurer's business processes. }\end{array}$ & od & 0,60 & do & 2,29 & $\begin{array}{l}\text { * No special measures for risk minimisation are } \\
\text { required, except for those aimed at retention of the } \\
\text { existing risk level. }\end{array}$ \\
\hline $\begin{array}{l}\text { MODERATE } \\
\text { RISK }\end{array}$ & $\begin{array}{l}\text { Risk realisation produces moderate } \\
\text { consequences on: a) solvency, adequacy and } \\
\text { coverage of technical provisions or b) efficient } \\
\text { functioning of business processes. }\end{array}$ & od & 2,30 & do & 4,39 & $\begin{array}{l}\text { *Undertaking measures and activities for risk } \\
\text { minimisation or retention at the existing level. }\end{array}$ \\
\hline MAJOR RISK & $\begin{array}{l}\text { Risk realisation has a major impact on: a) } \\
\text { solvency, adequacy and coverage of technical } \\
\text { provisions or b) seriously interferes with the } \\
\text { functioning of business processes. }\end{array}$ & od & 4,40 & do & 6,99 & $\begin{array}{l}\text { *Emergency measures for providing adequacy and } \\
\text { coverage of technical provisions and risk minimisation } \\
\text { which may lead to temporary or permanent insolvency. } \\
\text { *Measures for elimination qonsequences which have led } \\
\text { to serious interference with business processes. }\end{array}$ \\
\hline $\begin{array}{l}\text { EXTREMELY } \\
\text { HIGH RISK }\end{array}$ & $\begin{array}{l}\text { Risk realisation has an extremely high impact } \\
\text { on: a) solvency, adequacy and coverage of } \\
\text { technical provisions or b) directly interferes with } \\
\text { the functioning of business processes or leads to } \\
\text { their failure. }\end{array}$ & od & 7,00 & do & 10,00 & $\begin{array}{l}\text { *Urgent measures for servicing future obligations and } \\
\text { risk minimisation, activating Business Continuity Plan, } \\
\text { initiating activities for capital increase. } \\
\text { * Measures for elimination qonsequences and their } \\
\text { causes, which have led to disruption of business } \\
\text { processes. }\end{array}$ \\
\hline
\end{tabular}

Source - Author ${ }^{3}, 2016$.

The assessment of the risk size relating to the calculation of claims reserved and total calculated technical reserves and/or the risk assessment is made by type of insurance, by conducting the run-off analyses and LAT test

${ }^{3}$ Classification of risks, ranking of probability and severity of risk, presented in Figures 2., 3. and 4. are especially developed for and adapted to the insurance practice, taking into account the general (conceptual) solutions for military standards and standards in the field of occupational health and safety. 
(Liability Adequacy Test). By reconciling the recognized liabilities and the results of applied testing, the risks are minimized and the interests of the insured persons fully protected. An inherent part of the requirement for adequacy of technical reserves is the requirement that technical reserves are covered by equivalent assets of the Insurer, in terms of quality, structure and maturity, with the imperative management of exposure to concentration risk relating to receivables from the core business, investments in shares of other legal entities and subsidiaries, investment property, receivables from investments into debt securities, bank deposits and other forms of long-term and short-term investments. The concentration risk is managed both from the perspective of total investments in particular forms of property and the investments into the assets of a single issuer, holding of funds in a single bank or investments in a single real property.

The incurred losses directly affect the coverage of calculated technical reserves (indirectly the adequacy of technical reserves, as well), the ability to settle the current liabilities and the ability of insurers to permanently fulfill their liabilities to insured persons and/or comply with the capital requirements and the insurers' solvency. It is therefore essential to properly assess the weight and/or consequences of particular risks, especially where losses cannot be quantitatively stated.

In order to assess the impact of individual risks on the overall exposure of particular risk groups, all risks must be allocated the adequate ranking (which technically represents a risk weight and is a direct reflection of the risk severity and correlation among different risks).

The assessed risk size by risk groups has a (significantly) different impact on the amount of overall exposure which is why the impact of each risk group is separately assessed. This means that the assessment of the overall exposure of the company as a whole (non-life and life insurance) implies the need to assess the level of impact of each risk group on the overall exposure of the company as a whole and/or assign each risk group its appropriate ranking. A huge practical mistake in the process of risk management (as well as in other business activities) made not only by the company management, but also by its organizational units directly engaged in the risk management process is that they hold on to the assessment of individual risks, without trying to further define their effects on the overall exposure of the Insurer. In domestic practice, it is most common that the evaluations of the level of business organization are asked for and made for individual and isolated business stages, although the quality conclusions about the creditworthiness of the organizational level can be drawn only from the evaluation of the organizational level of all business activities of a company (Vidaković et al., 2015, p. 67).

Risk groups ranking ( i.e. the risk weight of particular risk groups) is, on the one hand, defined by the character and nature of the risks, and, on the other 
hand, by the size of the insurance company itself and factors of the financial and market environment. This fact answers the question why the initial assumptions about the impact of certain risk groups (subgroups) must be periodically reviewed.

From the above mentioned, it seems that the objective evaluation of risks is to a large extent conditioned by the quality of the process of identifying mutual links and impact among various risks and the ability to grasp the fact that some risks are, by their nature, opportunities for the insurance company to either benefit from or not, depending on the capacities of its administration and management. Systemic risk management is not possible unless the company risk management is delegated down the company structure to the lowest hierarchical functions/the employee level. Therefore, it is optimal (and even compulsory in big insurance companies) that all the key company functions/departments compose internal risk management reports from the aspect of their activities, which, in addition to the data, results of the performed analyzes, questionnaires for risk assessment and results of testing, should contain adequate conclusions and recommend measures to minimize the identified risks, as well as information on the implementation of measures adopted and ordered by the company management.

Of course, an integral part of the matrix model is a self-assessment procedure. It turned out that the self-assessment and obligation to compose selfassessment questionnaires (otherwise widely applied in the banking sector) allows the process of insurance risk management to include all the risks identified by the key organizational units of the company, on the basis of their competences regulated under the job specification by-law. In the process of selfassessment, the responsibility for assessing the risk exposure pertains to the first echelon, that is, hierarchically the highest level of administration and management bodies of the company; however, the requirement to meet the principle of objectivity points to the need to delegate the risk assessment process to the lowest organizational units of the company. In terms of methodology, the integration of a large number of risk assessments processes based on different risk approaches and risk inherences of particular organizational units of the Insurer, in practice, causes the need to assign the appropriate weight to each organizational unit, so as to evaluate both their estimated level and the competence of each of them.

Matrix model is, always and without exception, based on the assessment of specific individual risks. On the other hand, the estimated risk size of particular risk groups (and the size of risk of the risk subgroups within a group of insurance risks) is a function dependent on the estimated size of individual risks within specific risk groups and correlations, i.e. impacts and interrelations among individual risks within the risk groups, and as such represents a mathematically derived figure. 
Similarly, the estimated overall non-life and life exposure on the level of the insurance company as a whole is a function dependent on the assessed risk size per all risk groups and the assessed impact of risks of each individual group on the overall exposure, and as such is also a mathematically derived figure.

\section{PROCEDURE OF RISK ASSESSMENT THROUG MATRIX MODEL}

Determining the degree of risk severity (level, ranking) is not possible without appropriate quantitative methods for determining the amount of potential losses for a given level of probability and the amount of undervaluation or overvaluation of recognized assets and liabilities. The severity of risk and/or consequence ranking of each identified risk is determined based on the results of the applied quantitative models, i.e. the identified potential losses arising from market risk occurrences (using the VaR model - Value At Risk Method) at a given level of probability, undervaluation or overvaluation of technical reserves determined by the run-off and LAT test (Liability Adequacy Test) and other quantitatively expressed (possible, potential) losses. With a certain number of risks, the process of measurement and assessment is carried out at the level of lines of insurance and segment of insurance clients. However, with some individual risks, it is not possible to quantify the financial consequences of their occurrences by exact mathematical methods because such consequences are of a reputational or functional character - this is the reason for carrying out the subjective assessment of the risk size and determination of its level (rank), again taking into account the possible and expected risk consequences, interrelation and mutual influence among the risks. At the same time, it is possible to quantitatively determine the consequences of particular occurrences, so that the nominal amount of an actual or potential loss defines the risk effects and/or severity.

Numerical value of each level (rank, degree) of risk consequences is expressed by figures from 2. to 9 . In terms of methodology, when determining the risks consequences, we start from the size of potential losses and their impact on the amount of the guarantee reserve and compliance with capital requirements. In other words, the size of potential losses directly defines a quantitative rank of the impact of particular risks occurrences.

Nominally expressed risk levels and/or potential losses are defined based on figures presented in the risk matrix (which can also be otherwise expressed in percentages) and the risk significance threshold, which is particularly defined and adopted by the company management bodies. Risk significance threshold directly depends on the amount of calculated technical reserves, the amount of required regulatory capital, calculated solvency margin and guarantee reserves, 
the level of required regulatory capital, the level of calculated solvency margin and guarantee reserves, relative relation between the guarantee reserve and calculated solvency margin, provided always that the results of the LAT test as well as the amount, structure and dispersion of the insurance portfolio are taken into account. It is important to bear in mind that the matrix figures presented in the Figure 2 of this paper are not universal, meaning that every insurance company must define them separately, considering its risk management policies, size, organization and other relevant factors. Irrespective of the risk significance threshold used to assess the risk, insurers should specifically determine their limits of risk exposure, especially the limits in risk-taking and self-retention, in investing and depositing technical and guarantee reserves, in the price, currency and interest rate risk management and others.

In determining the risk significance threshold, it would be wrong to establish it at the level of regulatory capital, guarantee reserves, solvency margin or nominal discrepancy between guaranty reserves and solvency margin. This is because the risk matrix/risk assessment shoult result from the assessment of a number of risks totally different by their nature, character and impact on the business and solvency of the Insurer, whereas the consequences of particular risks are not quantitatively measurable.

In other words, if the matrix values would be applied to the guarantee reserve of domestic insurance companies with good capital ratios (i.e. with the guarantee reserves amounting to tens of millions of EUR, significantly exceeding the calculated solvency margin), a loss of several million euros would lead to the wrong conclusion that the risk exists at a low level, just because such amount of loss does not threaten to materially jeopardize the guarantee reserve and capital adequacy ratios. More specifically, let us assume that this is an insurance company with the guarantee reserve of EUR 40 million, solvency margin of 20 million EUR (i.e. the relative ratio between the guarantee reserves and solvency margin - 2: 1), with properly calculated technical reserves which are fully covered by the regulatory (top quality) assets, which has defined its significance threshold at the level of nominal discrepancy between the guarantee reserve and solvency margin, i.e. to the amount of 20 million EUR (for which the capital of the Insurer would otherwise be - strictly theoretically - allowed to fall for such a company to continue to meet the capital requirements). By applying the matrix values from the Figure 2 to the significance threshold defined in the above manner, the losses amounting to EUR 4 million would be categorized as the upper zone of low risk, given that such amount does not significantly affect the capital adequacy ratios. But, since the insurance companies, in addition to their liabilities for damages, must own funds to cover technical reserves and operating expenses, a loss of EUR 4 million (for example, accrued from uncollectable investments) could have a potentially adverse effect not only on the ability to settle the obligations but also on the financial result of 
the Insurer and the regular functioning of his business, especially bearing in mind that, unlike technical reserves, the guarantee reserves are, as a rule, mostly covered by the assets of low liquidity (real property for business purposes, receivables, etc.) which cannot be fast transformed into highly liquid, marketable assets.

From the above mentioned, it appears that the consequences of risks should be ranked based on their impact on capital requirements, settlement of liabilities and functioning of business processes.

Figure 4 - Ranking of risk severity/consequences

\begin{tabular}{|c|c|c|c|c|c|c|c|}
\hline \multicolumn{2}{|c|}{$\begin{array}{r}\text { SEVERITY OF } \\
\text { CONSEQUENCES } \\
\end{array}$} & $\begin{array}{c}\text { Quantitati } \\
\text { ve } \\
\text { ranking }\end{array}$ & Qualitative description of severity of consequences & \multicolumn{4}{|c|}{$\begin{array}{l}\text { Possible losses } \\
\text { (expressed as a \% of the } \\
\text { gularantee reserve) }\end{array}$} \\
\hline \multirow{2}{*}{ MINOR } & Insignificant & 1 & $\begin{array}{l}\text { Consequences are insignificant compared to the possibility to settle future obligations } \\
\text { and solvency or compared to the functioning of insurer's business processes }\end{array}$ & & & to & $0,08 \%$ \\
\hline & Minor (mild) & 2 & $\begin{array}{l}\text { Minor consequences compared to the possibility to settle future obligations and } \\
\text { solvency or compared to the functioning of insurer's business processes }\end{array}$ & from & $0,08 \%$ & to & $0,40 \%$ \\
\hline \multirow{2}{*}{ MODERATE } & Moderate & 3 & $\begin{array}{l}\text { Moderate consequences compared to the possibility to settle future obligations and } \\
\text { solvency or compared to the functioning of insurer's business processes }\end{array}$ & from & $0,40 \%$ & to & $1,44 \%$ \\
\hline & $\begin{array}{l}\text { Moderately } \\
\text { severe }\end{array}$ & 4 & $\begin{array}{l}\text { Moderately severe consequences compared to the possibility to settle future obligations } \\
\text { and solvency or compared to the functioning of insurer's business processes }\end{array}$ & from & $1,44 \%$ & to & $2,00 \%$ \\
\hline \multirow{2}{*}{ SIGNIFICANT } & Significant & 5 & $\begin{array}{l}\text { Significant consequences compared to the possibility to settle future obligations and } \\
\text { solvency orthey significantly interfere with the functioning of insurer's business } \\
\text { processes }\end{array}$ & from & $2,00 \%$ & to & $2,80 \%$ \\
\hline & Major & 6 & $\begin{array}{l}\text { Major consequences compared to the possibility to settle future obligations and } \\
\text { solvency or they highly significantly interfere with the functioning of insurer's business } \\
\text { processes }\end{array}$ & from & $2,80 \%$ & to & $3,60 \%$ \\
\hline \multirow{2}{*}{ MAJOR } & Extreme & 7 & $\begin{array}{l}\text { Consequences of risk realisation lead to the impossibility to settle future obligations } \\
\text { and to materiallysignificant solvency reduction, or directly interfere with the functioning } \\
\text { of business processes }\end{array}$ & from & $3,60 \%$ & to & $4,48 \%$ \\
\hline & Catastrophic & 8 & $\begin{array}{l}\text { Consequences of risk realisation may lead to permanentinability to settle future } \\
\text { obligations or to the failure of business processes }\end{array}$ & & from & & $4,48 \%$ \\
\hline
\end{tabular}

Source - Author, 2016.

Based on matrix figures presented in Figure 2., the Figure 5. below shows the nominally expressed risk ranges when the risk significance level amounts to EUR 3.2 million. 
Figure 5 - Risk matrix with nominally declared risk rank

\begin{tabular}{|c|c|c|c|c|c|c|c|c|c|c|}
\hline \multirow{3}{*}{ 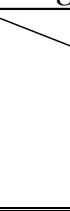 } & 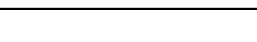 & & \multicolumn{8}{|c|}{ SEVERITY OF CONSEQUENCES } \\
\hline & \multirow{2}{*}{\multicolumn{2}{|c|}{ Qonsequences }} & 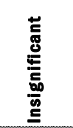 & $\begin{array}{l}\frac{\bar{\partial}}{\bar{E}} \\
\vdots \\
\frac{\grave{E}}{\Sigma}\end{array}$ & $\begin{array}{l}\frac{ \pm}{5} \\
\frac{\omega}{5} \\
\frac{0}{2} \\
\frac{0}{2}\end{array}$ & 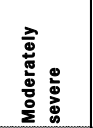 & 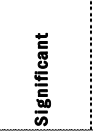 & $\frac{\overline{0}}{\frac{\pi}{2}}$ & 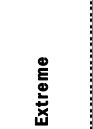 & 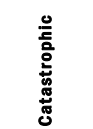 \\
\hline & & & $\overline{1}$ & 2 & 3 & 4 & 5 & 6 & 7 & 8 \\
\hline \multirow{10}{*}{ 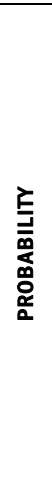 } & Practically unlikely event & 0,1 & 32.000 & 96.000 & 128.000 & 160.000 & 192.000 & 256.000 & 288.000 & 320.000 \\
\hline & Hardly identifiable probability & 0,2 & 96.000 & 160.000 & 256.000 & 320.000 & 416.000 & 480.000 & 576.000 & 640.000 \\
\hline & Highly unlikely, unusual event & 0,3 & 128.000 & 256.000 & 352.000 & 480.000 & 608.000 & 736.000 & 832.000 & 960.000 \\
\hline & Highly unlikely event & 0,4 & 160.000 & 320.000 & 480.000 & 640.000 & 800.000 & 960.000 & 1.120 .000 & 1.280 .000 \\
\hline & Relatively likely event & 0,5 & 192.000 & 416.000 & 608.000 & 800.000 & 992.000 & 1.216 .000 & 1.408 .000 & 1.600 .000 \\
\hline & Moderately likely event & 0,6 & 256.000 & 480.000 & 736.000 & 960.000 & 1.216 .000 & 1.440 .000 & 1.696 .000 & 1.920 .000 \\
\hline & Likely event & 0,7 & 288.000 & 576.000 & 832.000 & 1.120 .000 & 1.408 .000 & 1.696 .000 & 1.952 .000 & 2.240 .000 \\
\hline & Highly likely event & 0,8 & 320.000 & 640.000 & 960.000 & 1.280 .000 & 1.600 .000 & 1.920 .000 & 2.240 .000 & 2.560 .000 \\
\hline & Expected event & 0,9 & 352.000 & 736.000 & 1.088 .000 & 1.440 .000 & 1.792 .000 & 2.176 .000 & 2.528 .000 & 2.880 .000 \\
\hline & Certain event & 1 & 416.000 & 800.000 & 1.216 .000 & 1.600 .000 & 2.016 .000 & 2.400 .000 & 2.816 .000 & 3.200 .000 \\
\hline
\end{tabular}

Source - Author, 2016.

For each specific (individual) risk, it is necessary to perform an assessment of probability, whereby each level (degree, rank) of probability is assigned an adequate numeric value.

The numeric value of particular levels of probability is expressed by figures from 0.1 to 1 and their meaning can be seen in Figure 6. below.

Figure 6 - Ranking of probability

\begin{tabular}{|c|c|c|c|}
\hline \multicolumn{2}{|c|}{ PROBABILITY } & \multirow{2}{*}{$\begin{array}{c}\begin{array}{c}\text { Quantitative } \\
\text { ranking }\end{array} \\
\mathbf{0 , 1} \\
\end{array}$} & \multirow{2}{*}{$\begin{array}{l}\text { Qualitative description of risk realisation likelihood } \\
\text { Risk the realisation of which is almost an unlikely event }\end{array}$} \\
\hline NEGLIGIBLE & $\begin{array}{l}\text { Practically } \\
\text { unlikely event }\end{array}$ & & \\
\hline PROBABILITY & $\begin{array}{l}\text { Hardly } \\
\text { Identifiable }\end{array}$ & 0,2 & Risk realisation is possible only in exceptional circumstances \\
\hline \multirow{2}{*}{ LOW PROBABILITY } & $\begin{array}{l}\text { Highly } \\
\text { unlikely. }\end{array}$ & $\mathbf{0 , 3}$ & $\begin{array}{l}\text { Risk realisation is possible in small, countable number of cases as a consequence } \\
\text { of an unusual sequence of events or coincidence }\end{array}$ \\
\hline & $\begin{array}{l}\text { Highly } \\
\text { unlikely event }\end{array}$ & 0,4 & Risk realisation is possible in small i.e. limited number of cases \\
\hline \multirow{2}{*}{$\begin{array}{l}\text { MEDIUM } \\
\text { PROBABILITY }\end{array}$} & $\begin{array}{l}\text { Relatively } \\
\text { likely event }\end{array}$ & $\mathbf{0 , 5}$ & $\begin{array}{l}\text { Risk realisation is possible in the circumstances that are identifiable and } \\
\text { recognisable }\end{array}$ \\
\hline & $\begin{array}{l}\text { Moderately } \\
\text { likely event }\end{array}$ & 0,6 & Risk which may and may not be realised (equal likelihood 50\%: $50 \%$ ) \\
\hline \multirow{2}{*}{$\begin{array}{l}\text { HIGH } \\
\text { PROBABILITY }\end{array}$} & Likely event & 0,7 & Risk the realisation of which is possible and likely \\
\hline & $\begin{array}{l}\text { Highly likely } \\
\text { event }\end{array}$ & 0,8 & Risk the realisation of which is possible and highly likely \\
\hline \multirow{2}{*}{$\begin{array}{l}\text { EXTREMELY HIGH } \\
\text { PROBABILITY }\end{array}$} & $\begin{array}{l}\text { Expected } \\
\text { event }\end{array}$ & 0,9 & Risk which will almost certainly be realised \\
\hline & Certain event & 1 & Risk which will surely, that is, certainly be realised \\
\hline
\end{tabular}

Source - Author, 2016.

As will be seen from the examples included in this paper, the amount of overall exposure of non-life insurance has been estimated at a high risk level, although at a first glance it could be concluded, from the risk distribution (see chart 1 and risk assessment presented in figures 7., 8. and 9. below), that the 
risks are properly allocated. High risk stems from the fact that the liquidity risks are estimated at an extremely high risk level and insurance risks at a high risk level. In other words, the amount of the overall non-life and life exposure is far more affected by the aforementioned two groups of risk than by the operating and legal risks (which are estimated at a low risk level) and/or by the counterparty default risk and other risks (which are estimated at a medium risk level) and, in a certain sense, by the market risk.

Chart 1 - Distribution of risks based on the results of the non-life risks assessment $^{4}$

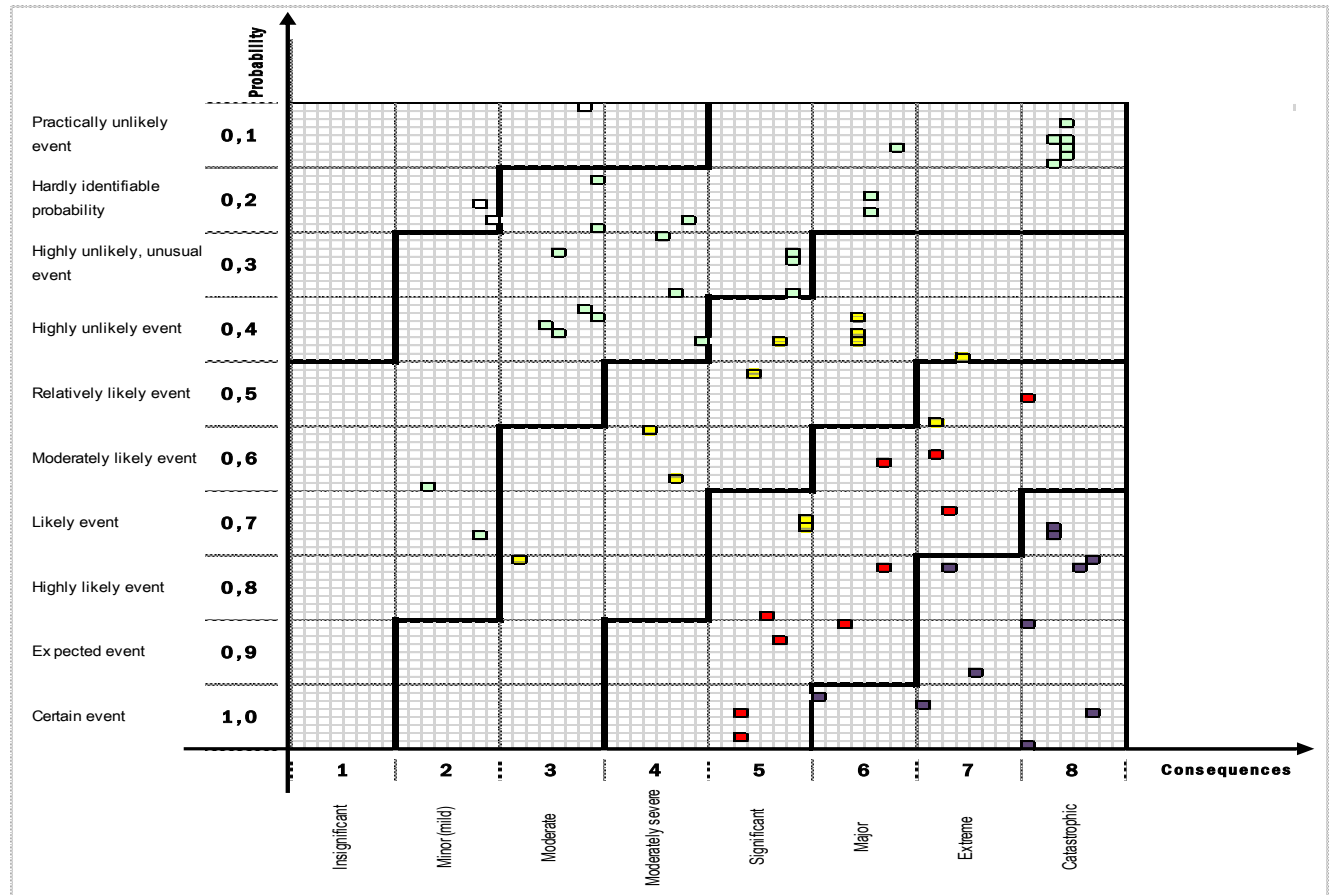

Source - Author, 2016.

Insurance risks are especially prominent compared to other risk groups, both for their influence (importance), and in terms of the large number of individual risks that determine the degree of insurance risk.

\begin{tabular}{|c|c|c|c|c|}
\hline INSIGNIFICANT RISK & from & 0,10 & to & 0,59 \\
\hline MINOR RISK & from & 0,60 & to & 2,29 \\
\hline MODERATE RISK & from & 2,30 & to & 4,39 \\
\hline MAJOR RISK & from & 4,40 & to & 6,99 \\
\hline EXTREMELY & fro & 7,00 & to & 10,00 \\
\hline
\end{tabular}


Compared to other risk groups, the insurance risks group is characterized by the fact that, within the group of a large number of individual risks that determine the size of the insurance risk, homogeneous risk subgroups are singled out and classified in adequate risk subgroups, such as: (1) risk of inadequate premium statement; (2) risk of inadequate formation of technical reserves; (3) insurance risk arising from cat events; (4) special insurance risks; (5) risk of inadequate assessment of the assumed risks; (6) risk of inadequately set self-retention and assuming the risks which exceed the self-retention and/or failure to cede the excess risks to coinsurance or reinsurance; and (7) other insurance risks.

For each specific (individual) risk, the first step is to define the rank of its consequences, starting from the numerical values in Figure 4. and the probability, starting from the numerical ranks in Figure 5. After that, the assessed size of each individual risk is defined as the product of risk severity (consequences) and probability.

Further on, the average weighted assessed risk size is calculated per all subgroups within the insurance risks group, as presented in Figure 6 below $^{5}$; such value represents the quotient of the sum of product of the assessed size of each individual risk and its effects expressed by a proper weight, on the one hand, and the sum of assigned weights per individual risks, on the other hand.

In order to simplify the procedure of assessment and theoretical basis of the model, the weights that express the impact and correlation, i.e. the risk interrelationships are, in the given examples, set identically to the specified range of the risk consequences.

Average weighted insurance risk is calculated as a quotient of the sum of product of the assessed size of risks of each risk subgroup and their weights and the sum of the assigned weights per all risk subgroups within the insurance risk group.

The risk size is separately calculated per all other risk groups, namely the liquidity risks, market risks, counterparty default risks, operating, legal and other significant risks. Average weighted risk is calculated by each of these risk groups also as a quotient of the sum of product of the assessed size of all individual risks within a group of risks and their weights and the sum of assigned weights per all individual risks within a particular risk group (see Figures 7. and 8. below).

\footnotetext{
${ }^{5}$ Risk matrices, presented in Figures 6., 7., 8. and 9. are composed in the form of Reporting Matrices, Monograph, Drljača, D. (2011)

Management accounting as a framework and instrument of assets and liabilities risk management in insurance companies, 103-106, in terms of methodology, developed and upgraded by the risk probability and consequences.
} 
Figure 7 - Assessment of the size of insurance risks. Source: Author, based on: Drljača, D. (2011)

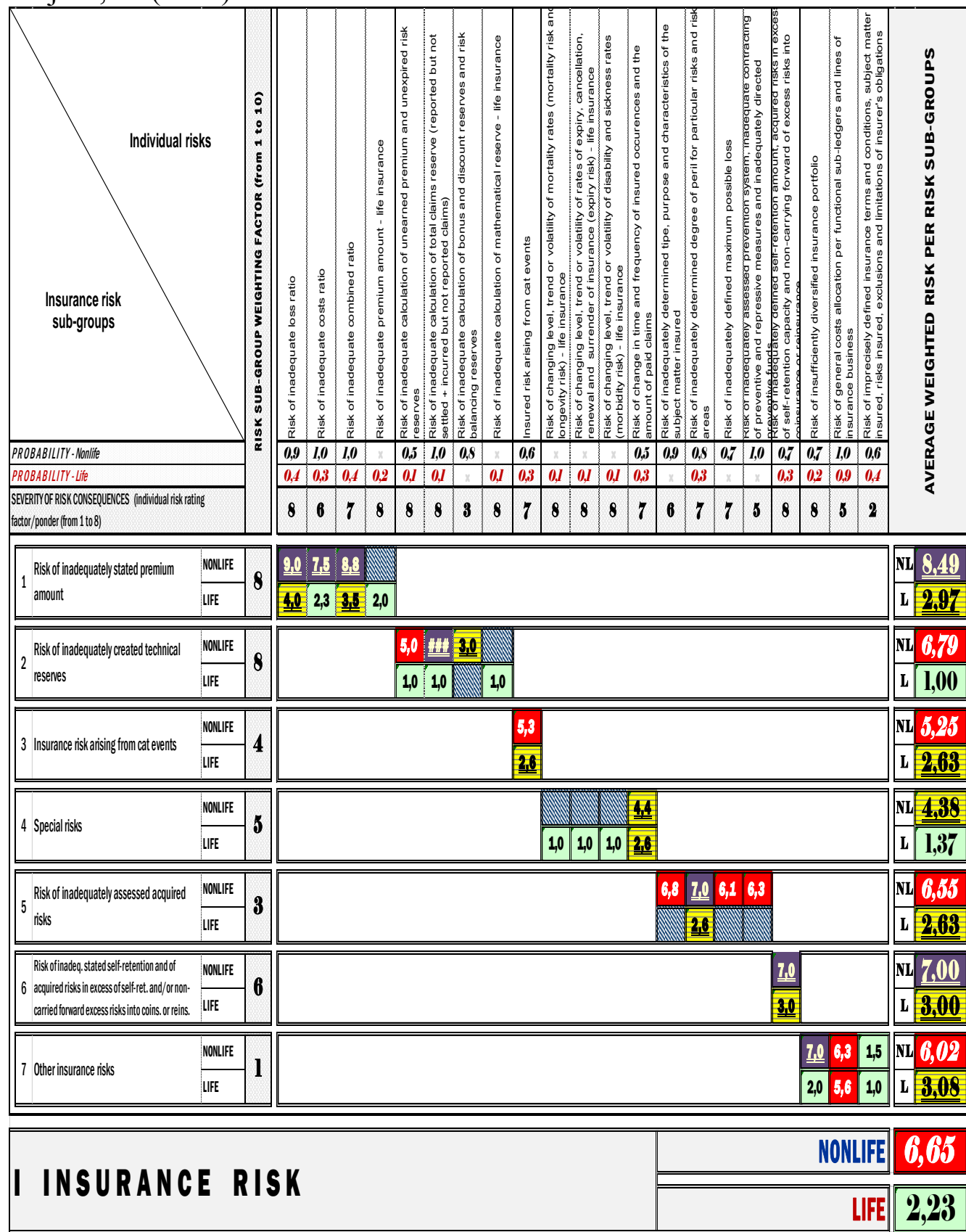

Source: Author, based on: Drljača, D. (2011) 
Figure 8-Assessment of the size of market risks, counterparty default risks and liquidity risks

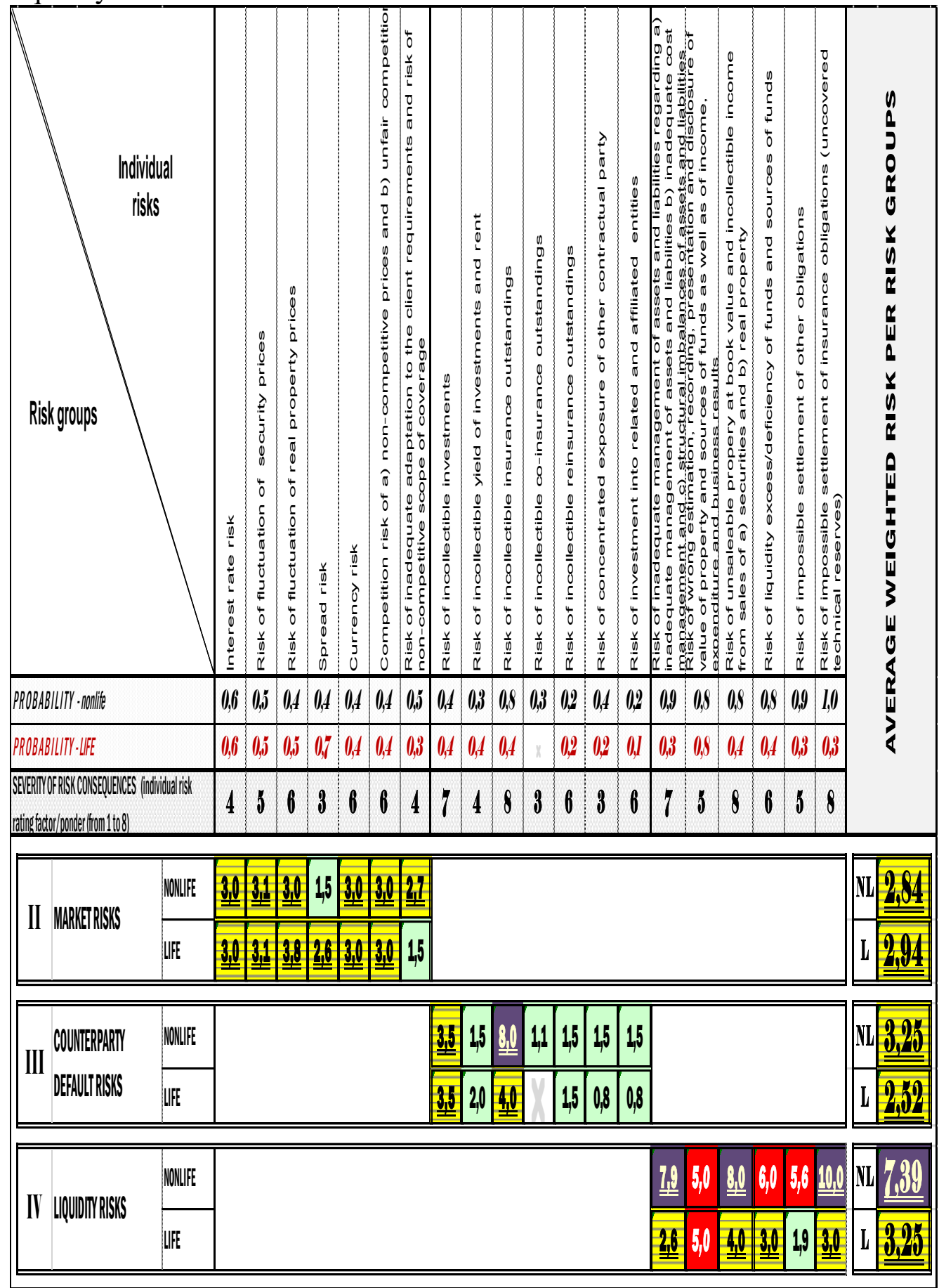

Source: Author, based on: Drljača, D. (2011) 
STR 43-65

Figure 9 - Assessment of the size of operating risks, legal risks and other significant risks

\begin{tabular}{|c|c|c|c|c|c|c|c|c|c|c|c|c|c|c|c|c|}
\hline $\begin{array}{l}\text { Individel } \\
\text { risks }\end{array}$ & & 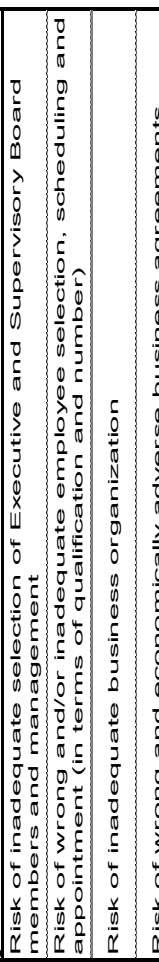 & 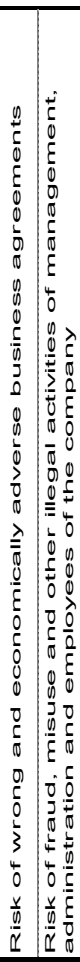 & 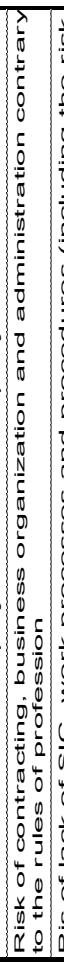 & 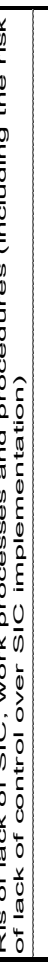 & 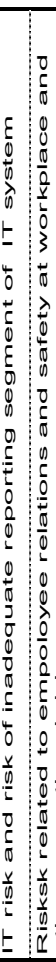 & $\begin{array}{l}0 \\
0 \\
0 \\
0 \\
0 \\
0 \\
0 \\
2 \\
2 \\
0 \\
0 \\
0 \\
0 \\
0 \\
0\end{array}$ & 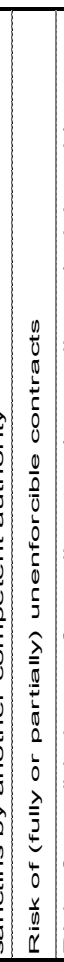 & 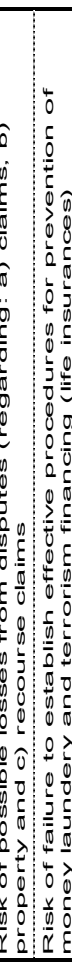 & 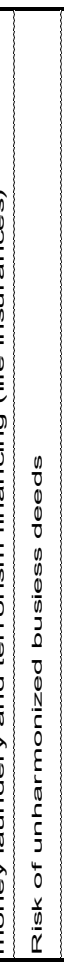 & 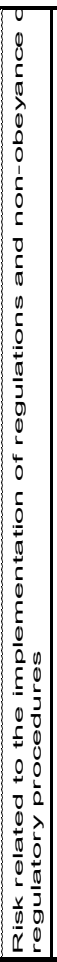 & $\begin{array}{l}0 \\
0 \\
\frac{0}{2} \\
\frac{0}{2}\end{array}$ & 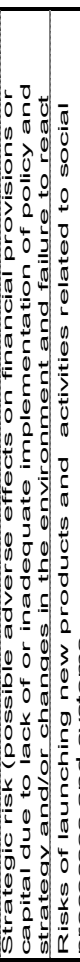 & 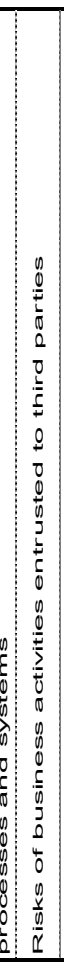 & 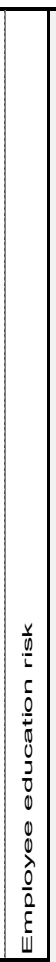 & 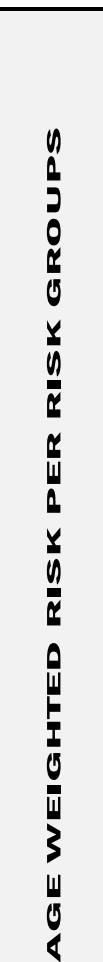 \\
\hline PPDBABIIITY -monlife & & \begin{tabular}{|l|l|l|l|}
0,6 & 0,4 & 0,6 & 0, \\
\end{tabular} & \begin{tabular}{l|l}
0,3 & 0,1 \\
\end{tabular} & 0,4 & 0,31 & 0,30 & 0 & 0,2 & $0,3 \quad x$ & 0,2 & 0,4 & & $0,70,4$ & 10,2 & 0,2 & $\frac{N}{11}$ \\
\hline PPOBABLIITY.JFE & & \begin{tabular}{|l|l|l|l|}
0,4 & 0,4 & 0,2 & 0, \\
\end{tabular} & \begin{tabular}{l|l}
0,3 & 0,1 \\
\end{tabular} & 0,3 & 0,21 & 0,80 & 0 & 0,2 & $0,0,2,2$ & 0,1 & 0,3 & & \begin{tabular}{|l|l|l|}
0,1 & 0,1 \\
\end{tabular} & 0,1 & 0,1 & 8 \\
\hline 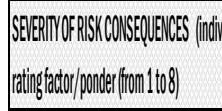 & & $\begin{array}{llll}6 & 5 & 4\end{array}$ & 43 & 3 & j & b? & & & b? & 3 & 3 & $j$ & ju 4 & 2 & 3 & \\
\hline \multirow{2}{*}{ T OPERAOWLARSISIS } & MOWLIF: & 4,521 & $1,50,04$ & 1,5 & 19 & & & & & & & & & & & NL 2,24 \\
\hline & UlFE & $3, \frac{2,5}{2} 10$ & $1,50,4$ & 11 & $13:$ & 190 & & & & & & & & & & 1,60 \\
\hline \multirow{2}{*}{ III IEEARASISS } & MVillF: & & & & & & & 10 & 19 & 0,8 & 1,5 & & & & & $\mathrm{NL} \quad 1,30$ \\
\hline & Ulf: & & & & & & & & $0,60,5$ & 0,4 & 11 & & & & & $\mathrm{~L} 0,09$ \\
\hline \multirow{2}{*}{ III } & Maille: & & & & & & & & & & & & 44 & 0,5 & & $\mathrm{NL} 2,00$ \\
\hline & LIF: & & & & & & & & & & & & $0,60,5$ & 0,3 & 0,4 & L 1,18 \\
\hline
\end{tabular}

Source: Author, based on: Drljača, D. (2011) 
Average weighted risk of non-life and life insurance at the level of the company as a whole is calculated as the quotient of the sum of the product of the assessed size per each risk group and their weights and the sum of assigned weights per all risk groups. The weight of risk groups are defined within the range of 1 to 10, and individually assigned to each risk group, as stated above, depending on the amount of impact of group risk on the overall exposure of the insurance company as a whole.

The Figure 9. shows that the risks of non-life insurance have been assessed at the level of a high risk, and life insurance risks at the level of medium risk. High non-life insurance risk stems from the fact that the liquidity risks are assessed at the level of extremely high risk and the insurance risks at the level of high risk, having in mind that the impact of these risk groups on the overall exposure exceeds by far other risk groups.

Therefore, the overall exposure is predominantly defined by the severity of particular risks (and their probabilities) rather than the distribution of individual risks per specific risk zones (levels), as is clear from the information contained in Chart 1 and Figure 10. below.

Figure 10 - Estimated amount of overall non-life and life exposure at the level of the company as a whole

\begin{tabular}{|c|c|c|c|c|}
\hline \multirow{2}{*}{ TOTAL COMPANY RISK } & \multicolumn{2}{|l|}{ NONLIFE } & MANOR RISK & 4,58 \\
\hline & \multicolumn{2}{|l|}{ LIFE } & $\begin{array}{l}\text { MODERATE } \\
\text { RISK } \\
\end{array}$ & 2,38 \\
\hline \multirow{2}{*}{ 1. INSURANCE RISKS } & NONLIFE & \multirow{2}{*}{10} & MANOR RISK & 6,65 \\
\hline & LIFE & & MINOR RISK & $\mathbf{2 , 2 3}$ \\
\hline \multirow{2}{*}{ | 2. MARKET RISKS } & \begin{tabular}{|l|l|} 
NONLIFE \\
\end{tabular} & \multirow{2}{*}{$\boldsymbol{7}$} & MODERATE-RISK & $\underline{\underline{\underline{\underline{2,84}}}}$ \\
\hline & LIFE & & MODERATE RISK & $\underline{2,94}$ \\
\hline \multirow{2}{*}{ 3. COUNTERPARTY DEFAULT RISKS } & NONLIFE & \multirow{2}{*}{8} & MODERATE RISK & $\underline{\underline{3,25}}$ \\
\hline & LIFE & & MODERATE RISK & 2,52 \\
\hline \multirow{2}{*}{ 4. LIQUIDITY RISKS } & NONLIFE & \multirow{2}{*}{$\mathbf{9}$} & EXIR. HICH RISK & $\underline{7.38}$ \\
\hline & LIFE & & MODERATE RISK & $\underline{\underline{\underline{3,25}}}$ \\
\hline \multirow{2}{*}{ 5. OPERATIONAL RISKS } & NONLIFE & \multirow{2}{*}{$\mathbf{3}$} & MINOR RISK & 2,24 \\
\hline & LIFE & & MINOR RISK & 1,65 \\
\hline \multirow{2}{*}{ 6. LEGAL RISKS } & TONLIFE & \multirow{2}{*}{4} & MINOR RISK & $1, \mathbf{3 9}$ \\
\hline & LIFE & & MINOR RISK & 0,72 \\
\hline \multirow{2}{*}{ 7. OTHER RELEVANT RISKS } & NONLIFE & \multirow{2}{*}{2} & MODERATE RISK & 2,89 \\
\hline & LFE & & MINOR RISK & 1,18 \\
\hline
\end{tabular}

Source: Author, based on: Drljača, D. (2011) 


\section{CONCLUSION}

Matrix model, updated by appropriate methodological tools and instruments presented in this paper, is one of the most practical models for assessing both the individual risks and the overall exposure of non-life and life insurance at the level of the insurance company as a whole. This model is characterized by the relative simplicity and transparency, as well as comparability and traceability of the risk trends over time. Although the estimated risk size is determined as the product of risk severity and probability, which are quantitatively expressed through appropriate levels or ranges, the assessment of the risk size is not possible without previous identifying, defining and quantifying the correlations among the risks (both among individual risks within specific risk groups and among the risk groups themselves).

Assessment of the company's overall exposure is preceded by a process of risk measurement through the application of various quantitative models (especially with the insurance risk, market risks and liquidity risks) without which it would be impossible to determine their consequences (except for those risks where it is not possible to use the mathematical methods to quantify the losses and whose ranks are determined by qualitative methods). Unlike the measurement and evaluation of individual risks, the assessed risk size of particular risk groups and overall exposure of the company represents a mathematically derived size, whose amount is defined by the risk correlation as represented by a system of weights, both within particular risk groups (among individual risks) and among the risk groups themselves.

The described methodology clearly indicates the need for a systemic approach to the risk measurement and assessment activities and the necessity to include i.e. structure the risk information as an integral part of the reporting system in insurance companies, which allows the risk management process to strengthen the security and solvency of an insurance company, be a source of important information for a quality management of the company and insurance supervision and a means of reporting to equity holders, policyholders and the public.

\section{REZIME \\ PROCENA RIZIKA U DRUŠTVIMA ZA OSIGURANJE PRIMENOM MATRIČNOG MODELA}

Utemeljenje sistema upravljanja rizicima i sprovođenje sopstvene procene rizika u društvima za osiguranje (ORSA-Own Risk and Solvency Assessment), pored primene niza modela kojima se obezbeđuje merenje potencijalnih gubitaka i procena visine rizika, pretpostavlja prethodno definisanje prioriteta rizika $\mathrm{i}$ 
limita za nošenje rizika, kao i periodično preispitivanje okvira za prepoznavanje, kvantifikovanje i procenu rizika. Na taj način obezbeđuje se optimalna alokacija i upotreba raspoloživih finansijskih, tehničkih, informatičkih, ljudskih i svih drugih raspoloživih resursa. U postupku utvrđivanja procedura i uspostavljanja odgovarajuće organizacije upravljanja rizicima, osiguravači na prvom hijerarhijskom nivou najpre vrše izbor modela za kvantifikovanje mogućih gubitaka, testiranje dovoljnosti obračunatih tehničkih rezervi LAT testom (Liability adequacy test) i procenu visine pojedinačnih rizika. Na drugom hijerarhijskom nivou, vrši se izbor modela kojim se vrši merenje i procena solventnosti, odnosno procena dovoljnosti kapitala, kao i modela za procenu ukupnog rizika na nivou društva kao celine, među kojima centralno mesto pripada matričnom modelu. Matrični model obezbeđuje dokumentovan i sistematičan pristup rizicima, obezbeđujući informacije uporedive u vremenu, delimično i između samih osiguravajućih društava.

Ključne reči: adekvatnost, rizici, procena, solventnost, matrice, upravljanje rizicima, modeli, merenje, kompanija...

\section{REFERENCES}

1. Baller, M. (2012). The development of the german life insurance market how do the companies answer the new challenges, Achieved Results and Prospects of Insurance Market Development in Modern World. (pp. 189197). Serbia: University of Belgrade - Faculty of Economics Publishing Centre.

2. Čabrilo, S., Savić-Šikoparija, T., \& Kliček, T. (2013). Istraživanje konflikata u funkciji upravljanja promenama u javnim preduzećima. Poslovna ekonomija, 1, 100. Univerzitet Edukons, Sremska Kamenica.

3. Directive 2009/138/EC of the European Parliament and of the Council of 25 November 2009 on the taking-up and pursuit of the business of Insurance and Reinsurance (Solvency II), COD 2007/0143. (2009).

4. Drljača, D. (2011). Strukturno usklađivanje aktive i pasive u svetlu zahteva projekta Solventnost II, Nadzor i kontrola poslovanja osiguravajućih Kompanija (pp. 308-327). Beograd: Univerzitet u Beogradu - Ekonomski Fakultet.

5. Drljača, D. (2011). Upravljačko računovdstvo kao okvir i instrument upravljanja rizicima aktive i pasive u društvima za osiguranje. (pp. 1-448). Beograd: Centar za kulturu Mladenovac.

6. Mitroff, I.I., Emshofff, J.R., \& Kilmann, R.H. (1979). A methodology for strategic problem solving, Assumptional analysis. Management Science, 583-593. 
7. Nikolić, B., \& Gemović, B. (2009). Zaštita i zdravlje na radu i zaštita životne sredine. Primena metode procene rizika na radnom mestu i u radnoj okolini. (pp. 49-56). Banja Luka: Institut zaštite, ekologije i informatike.

8. Ristić, D. (2013). A tool for risk assessment, Safety engineering. (pp. 121127). Serbia: University of Niš - Faculty of Occupational Safety.

9. Odluka o sistemu upravljanja u društvu za osiguranje/reosiguranje. Službeni glasnik Republike Srbije, (2015). 51.

10. Odluka o adekvatnosti kapitala društva za osguranje/reosiguranje. Službeni glasnik Republike Srbije, (2015). 51.

11. USA Department of defence. (1993). MIL-STD-882C: System safety program requirements. MSC Number F6861.

12. Vidaković, S.B., Ljubojević, M., \& Banda, I. (2015). Analiza nivoa organizovanosti poslovanja preduzeća. Poslovna ekonomija, 17(2), 67-68. Univerzitet Edukons, Sremska Kamenica.

13. Zakon o osiguranju. Službeni glasnik Republike Srbije, (2014). 139.

Ovaj rad je primljen 12.07.2016., a na sastanku redakcije časopisa prihvćen za štampu 24.03.2017. godine. 